\title{
Pepper plants growth, yield, photosynthetic pigments, and total phenols as affected by foliar application of potassium under different salinity irrigation water
}

\author{
M. M. Hussein ${ }^{1 *}$, S. Y. El-Faham ${ }^{2}$, A. K. Alva ${ }^{3}$

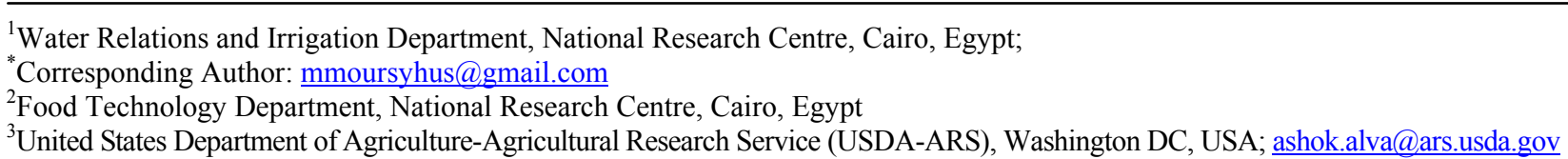

Received 14 December 2011; revised 30 January 2012; accepted 11 February 2012

\begin{abstract}
Irrigation with high salinity water influences plant growth, production of photosynthetic pigments and total phenols, leading to reduction in crop yield and quality. The objective of this study was to investigate the effects of potassium $(K)$ foliar application in mitigating the negative effects of salt stress on pepper plants. A greenhouse experiment was conducted to investigate the effects of foliar application of potassium (K) on pepper plants grown with different salinity water irrigation (3000 and $6000 \mathrm{ppm}$ as compared to tap water with salinity level of $\mathbf{3 0 0} \mathbf{p p m}$ ). Irrigation using high salinity water decreased plant height, biomass production, and fruit yield as compared to those of the plants irrigated by tap water. Photosynthetic pigments and total phenols increased in the former as compared to those of the latter plants. The most serious affect was for the plants under highest salinity irrigation (6000 ppm) as compared to that of the plants under moderate salinity irrigation (3000 ppm). Foliar application of potassium mono phosphate (KMP) at $200 \mathrm{ppm}$ concentration increased the plant growth, biomass production, and fruit yield. Chlorophyll_a content and total phenols increased significantly with foliar application of 100 ppm KMP. Further increase in foliar KMP concentration to $200 \mathrm{ppm}$ had no significant benefits on photosynthetic pigments and total phenols content. This study demonstrated that foliar application of KMP, to some extent, mitigated the negative effects of high salinity water irrigation on pepper plant growth and fruit yield.
\end{abstract}

Keywords: Diluted Sea Water; Potassium Mono Phosphate; Chlorophyll_a; Chlorophyll_b;
Carotenoids; Potassium Nutrition

\section{INTRODUCTION}

Pepper (Capsicum annuum L.) plants are sensitive to drought stress and moderately sensitive to salt stress $[1,2]$. In greenhouse conditions, pepper plants grown under water deficit with excess fertilizers accumulate large amounts of sodium $(\mathrm{Na})$, potassium $(\mathrm{K})$, phosphorus $(\mathrm{P})$, and chloride $(\mathrm{Cl})([3])$. This leads to an excess ion uptake and an imbalance of various mineral elements. Plants exposed to high salinity exhibit membrane destabilization and inhibition of exposed photosynthetic capacity ([4]).

Negative effects of salinity on pepper plants can be overcome, to some extent, by foliar application of macro and/or micro nutrients [5]. Studies have also shown an increase in pepper yields with foliar application of calcium (Ca) [6] and K [7]. Foliar application of P, K, zinc $(\mathrm{Zn})$ and manganese $(\mathrm{Mn})$ significantly increased yield and cold tolerance in maize [8].

The physiological effects of interactions between salinity and mineral nutrition in horticultural crops are extremely complex. Crop performance may be adversely affected by salinity-induced nutritional disorders. These disorders may result from the effect of salinity on nutrient availability, competitive uptake and transport or partitioning of nutrients within the plant. For example, salinity reduces phosphate uptake in crops grown in soils primarily by reducing phosphate availability. In solution cultures, ion imbalance may primarily result from competitive interactions. Increased uptake of $\mathrm{Na}^{+}$and $\mathrm{Cl}^{-}$ under saline growing conditions may decrease $\mathrm{K}^{+}$and $\mathrm{NO}_{3}^{-}$uptake, respectively. Salinity can also cause a combination of complex interactions that affect plant metabolism, nutrient requirement, and susceptibility to injury [9]. 
Optimum and balanced availability of macro and micro nutrients can mitigate negative effects of some stress factors on growth, yield, and quality of vegetable crops ([10-12]). The objective of this study was to investigate the effects of foliar application of $\mathrm{K}$ on pepper plants in mitigating negative effects of salt stress.

\section{MATERIALS AND METHODS}

\subsection{Preparation of Pots}

A pot experiment was conducted in a greenhouse in the National Research Centre, Dokki, Cairo, Egypt during the 2007 summer season using Pepper (Capsicum annum L.) variety Balady red. The treatments were as follows: 1) two irrigation water salinity levels compared to tap water with salinity levels of: 6000, 3000, and 300 ppm, or $9.38,4.69$, and $0.47 \mathrm{dS} / \mathrm{m}$, respectively; 2) foliar spray of distilled water compared to water containing 100 or 200 ppm potassium mono phosphate (KMP). There were six replications of each treatment.

Metallic pots of $35 \mathrm{~cm}$ diameter and $50 \mathrm{~cm}$ depth were used. The inner surface of the pot was coated with three layers of bitumen to prevent direct contact between the soil and metal, and $2 \mathrm{~kg}$ of gravel (particles about $2-3 \mathrm{~cm}$ ) was placed at the bottom of the pot. Each pot contained $30 \mathrm{~kg}$ of air dried clay loam soil (Table 1). Calcium super phosphate $(6.8 \% \mathrm{P})$ and potassium sulfate $(40.3 \% \mathrm{~K})$ were added (broadcasted on the soil surface) to the soil in the pot at 4.5 and 2.5 $\mathrm{g} /$ pot, respectively.

\subsection{Planting}

Pepper seedlings were transplanted on July 15, 2007, and thinned to 3 plants per pot after two weeks. Nitrogen was applied as ammonium sulfate $(20.5 \% \mathrm{~N})$ in three applications of $9.0 \mathrm{~g} /$ pot each, 2, 4, and 6 weeks after planting. Diluted seawater to attain two salinity levels (3000 and $6000 \mathrm{ppm}$ ) were used for high salinity irrigation began two days after planting. For those treatments, each high salinity water irrigation was alternated with fresh water irrigation. The pots were irrigated on three days frequency. Foliar application KMP was done twice, i.e. 21 and 35 days after planting.

\subsection{Response Parameters}

At the completion of the experiment (120 days after planting), plant height was measured. Leaves were stripped from the plants and leaf area was measured for all the leaves per plant. Fruit length and diameters were measured. Fresh weights of plant stem, leaves, and fruits were recorded. These plant parts were dried at $70^{\circ} \mathrm{C}$ for $72 \mathrm{~h}$ and dry weights were also recorded.

Concentrations of photosynthetic pigments i.e. Chlorophyll_a, Chlorophyll_b and total carotenoids were measured in leaf samples taken 120 days after planting following the procedure described by von Wettstien et al. [13].

Total Phenols in leaves were determined using the method described by Titto [14]. Data collected were subjected to the statistical analysis as described by Snedecor and Cochran [15].

\section{RESULTS AND DISCUSSION}

\subsection{Salt Stress}

\subsubsection{Growth}

Irrigation with high salinity water significantly decreased pepper plants height, leaf area, fruit length and

Table 1. Some physical and chemical characteristics of the soil used in this study.

\begin{tabular}{|c|c|c|c|c|c|c|c|c|c|c|c|c|}
\hline \multicolumn{13}{|c|}{ A. Particle size analysis } \\
\hline \multicolumn{3}{|c|}{ Coarse Sand $(>200 \mu \mathrm{m})$} & \multicolumn{2}{|c|}{ Fine Sand $(200-20 \mu \mathrm{m})$} & \multicolumn{3}{|c|}{ Silt $(20-2 \mu \mathrm{m})$} & \multicolumn{5}{|c|}{ Clay $(<2 \mu \mathrm{m})$} \\
\hline \multicolumn{13}{|c|}{$(\%)$} \\
\hline \multicolumn{3}{|c|}{7.20} & \multicolumn{2}{|l|}{14.25} & \multicolumn{3}{|c|}{30.22} & \multicolumn{5}{|c|}{48.33} \\
\hline \multicolumn{13}{|c|}{ B. Soil chemical analysis } \\
\hline \multirow{2}{*}{$\mathrm{pH}(1: 2.5)$} & \multirow{2}{*}{$\begin{array}{c}\mathrm{EC}\left(\mathrm{dS} \cdot \mathrm{m}^{-1}\right) \\
(1: 5)\end{array}$} & \multirow{2}{*}{$\mathrm{CaCO}_{3}(\%)$} & \multirow{2}{*}{$\begin{array}{c}\mathrm{CEC} \\
\left(\mathrm{C} \text { mole } \cdot \mathrm{Kg}^{-1}\right)\end{array}$} & \multirow{2}{*}{$\mathrm{OM}(\%)$} & \multicolumn{8}{|c|}{ Soluble cations and anions (meq/100g soil) } \\
\hline & & & & & $\mathrm{Na}^{+}$ & $\mathrm{K}^{+}$ & $\mathrm{Ca}^{2+}$ & $\mathrm{Mg}^{2+}$ & $\mathrm{CO}_{3}$ & $\mathrm{HCO}_{3}^{-}$ & $\mathrm{Cl}^{-}$ & $\mathrm{SO}_{4}^{2-}$ \\
\hline 7.15 & 1.3 & 2.53 & 33.5 & 1.3 & 1.82 & 0.23 & 2.38 & 1.27 & 0.0 & 0.91 & 1.9 & 1.89 \\
\hline \multicolumn{5}{|c|}{ Available macro-nutrients $(\mathrm{g} / \mathrm{kg})$} & \multicolumn{8}{|c|}{ Available micro-nutrients (mg/kg) } \\
\hline $\mathrm{N}$ & \multicolumn{2}{|l|}{$P$} & K & & \multicolumn{2}{|l|}{$\mathrm{Zn}$} & \multicolumn{2}{|l|}{$\mathrm{Fe}$} & \multicolumn{2}{|c|}{$\mathrm{Mn}$} & \multicolumn{2}{|c|}{$\mathrm{Cu}$} \\
\hline 4.7 & \multicolumn{2}{|c|}{2.5} & 9.5 & & \multicolumn{2}{|l|}{3.1} & \multicolumn{2}{|l|}{4.8} & \multicolumn{2}{|c|}{7.3} & \multicolumn{2}{|l|}{5.2} \\
\hline
\end{tabular}

$\mathrm{OM}=$ Organic matter; $\mathrm{CEC}=$ Cation Exchange Capacity 
diameter, as well as stem, leaves and fruit weight as compared to those of the plants irrigated by tap water (Table 2). Chartzoulakis and Klapaki [16] reported significant reduction in growth of pepper plants irrigated with water containing 100 and $150 \mathrm{mM} \mathrm{NaCl}$. They also reported significant reductions in plant height, leaf area, and dry weight of the plants irrigated with water containing $\geq 25$ $\mathrm{mM} \mathrm{NaCl}$.

These adverse effects of salt stress may be due to the effects of salts on the availability and uptake of water leading to decreased water content in the plant tissues which altered the metabolic processes inside the cells. Furthermore, increased salt content in the irrigation water may cause direct and indirect effects on leaf water relations and stomatal closure which influence $\mathrm{CO}_{2}$ exchange and photosynthetic rate. Increased salt content in irrigation water may be directly toxic to plants, which in turn, lowered carbohydrate accumulation in the plants $[17,18]$.

Furthermore, negative effects of salinity have been attributed to disturbance in either protein assimilation [19, 20], mineral uptake and distribution [21], activities of growth hormones [22-24], enzymes activities [25,26] and oxidative defense ([25-27]).

\subsubsection{Photosynthetic Pigments}

Concentrations of chlorophyll_a (chl_a), chlorophyll_b (chl_b), carotenoids, or total phenols increased with increased salinity in irrigation water (Table 3). The highest value of chl_a: chl_b ratio was in leaves of the plants irrigated by saline water with $\mathrm{EC}=4.69 \mathrm{dS} / \mathrm{m}$. Mousavi, et al. [28] also reported a decrease in chlorophyll_a and b in young olive cultivars with an increase in salinity up to $40 \mathrm{mM}$. The results of this study are in agreement with those of Azooz et al. [29] for sorghum, Dagar et al. [30] for Salvadorapersica, and Lee [2] for hot pepper.

The reduction in leaf chlorophyll content of the plants grown in $\mathrm{NaCl}$ stress has been attributed to the destruction of chlorophyll pigments and instability of the pigment protein complex [31]. Furthermore, increased salt content also interferes with protein synthesis and influences the structural component of chlorophyll [32].

\subsubsection{Total Phenols}

Concentration of total phenols in pepper leaves significantly increased with an increase in irrigation water salinity (Table 3). Chartzoulakis [33] reported that total phenol content in olive leaves was not affected by moderate $\mathrm{NaCl}$ salinity $\left(\mathrm{EC}_{\mathrm{w}}\right.$ of $\left.5 \mathrm{dS} / \mathrm{m}\right)$. Ben Dkhil and Denden [34] observed greater accumulation of sugar and phenols in Abelmoschus esculentus L. (Moench.) seedlings with an increase in salinity of up to $100 \mathrm{mM} \mathrm{NaCl}$.

\subsection{Foliar Application of KMP}

\subsubsection{Growth}

Foliar application of KMP significantly increased the plant height, leaf area, fruit diameter, stem and fruit fresh and dry weights (Table 4). El-Tohamy et al. [35] re-

Table 2. Growth response of pepper plants to irrigation by tapwater or two high salinity water.

\begin{tabular}{|c|c|c|c|c|c|c|c|c|c|c|c|}
\hline \multirow{2}{*}{$\begin{array}{l}\text { Salinity } \\
(\mathrm{dS} / \mathrm{m})\end{array}$} & \multirow{2}{*}{$\begin{array}{c}\text { Plant } \\
\text { height }(\mathrm{cm})\end{array}$} & \multirow{2}{*}{$\begin{array}{l}\text { No. of } \\
\text { Leaves }\end{array}$} & \multirow{2}{*}{$\begin{array}{l}\text { Leaf area/plant } \\
\left(\mathrm{cm}^{2}\right)\end{array}$} & \multicolumn{2}{|c|}{ Fruit } & \multicolumn{3}{|c|}{ Fresh weight (g) } & \multicolumn{3}{|c|}{ Dry weight (g) } \\
\hline & & & & $\begin{array}{l}\text { Length } \\
(\mathrm{cm})\end{array}$ & $\begin{array}{l}\text { Diameter } \\
(\mathrm{cm})\end{array}$ & Stem & Leaves & Fruits & Stem & Leaves & Fruit \\
\hline 0.47 (tap water) & 50.7 & 48 & 1721 & 4.8 & 4.6 & 30.1 & 26.7 & 24.0 & 4.5 & 5.2 & 5.9 \\
\hline 4.69 & 36.5 & 32 & 1160 & 3.7 & 3.5 & 19.6 & 19.5 & 20.7 & 4.3 & 4.5 & 4.7 \\
\hline $\operatorname{LSD}(\mathrm{P} \leq 0.05)$ & 2.68 & NS & 44.5 & 1.0 & 1.3 & 7.5 & 6.5 & 9.0 & NS & 0.8 & 1.6 \\
\hline
\end{tabular}

LSD = Least Significant Difference; NS = Non Significant.

Table 3. Effects of irrigation with tap water or two high salinity water on photosynthetic pigments and total phenols in leaves of pepper plants.

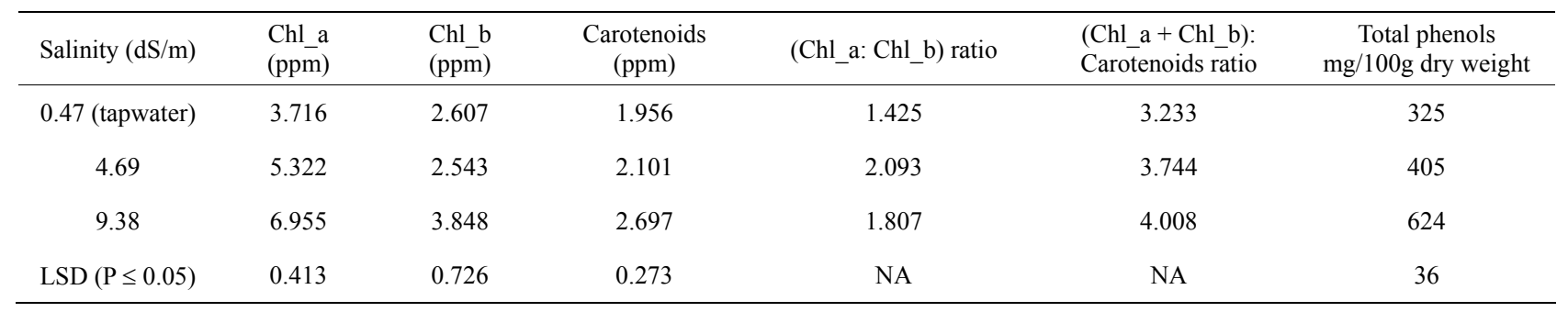

NA $=$ Not applicable; LSD = Least Significant Difference; Chl $=$ Chlorphyll. 
Table 4. Growth response of pepper plants to foliar application of different concentrations of potassium mono phosphate (KMP).

\begin{tabular}{|c|c|c|c|c|c|c|c|c|c|c|c|}
\hline \multirow{2}{*}{ KMP (ppm) } & \multirow{2}{*}{$\begin{array}{c}\text { Plant } \\
\text { height }(\mathrm{cm})\end{array}$} & \multirow{2}{*}{$\begin{array}{l}\text { No of } \\
\text { leaves }\end{array}$} & \multirow{2}{*}{$\begin{array}{c}\text { Area of } \\
\text { leaves }\left(\mathrm{cm}^{2}\right)\end{array}$} & \multicolumn{2}{|c|}{ Fruit } & \multicolumn{3}{|c|}{ Fresh weight (g) } & \multicolumn{3}{|c|}{ Dry weight (g) } \\
\hline & & & & Length $(\mathrm{cm})$ & Diameter $(\mathrm{cm})$ & Stem & Leaves & Fruits & Stem & Leaves & Fruits \\
\hline $0^{(1)}$ & 36.0 & 33 & 870 & 3.6 & 3.4 & 15.4 & 16.7 & 14.7 & 3.3 & 3.3 & 3.3 \\
\hline 100 & 40.0 & 37 & 1176 & 4.0 & 3.6 & 25.1 & 21.6 & 20.2 & 3.5 & 4.0 & 4.3 \\
\hline 200 & 46.4 & 39 & 1704 & 4.7 & 4.0 & 23.7 & 21.1 & 23.6 & 4.7 & 5.0 & 6.2 \\
\hline $\operatorname{LSD}(\mathrm{P} \leq 0.05)$ & 6.7 & NS & 79.6 & NS & 0.5 & 8.7 & NS & 2.2 & 1.3 & NS & 2.04 \\
\hline
\end{tabular}

${ }^{(1)}$ Distilled Water; NS = Non Significant; LSD = Least Significant Difference.

ported that foliar application of nutrients, especially $\mathrm{P}$, $\mathrm{Ca}$ and $\mathrm{K}$, can improve growth and yield of pepper plants grown in sandy soils during winter season. Fawzy et al. [36] discovered that the best vegetative growth, total yield, and fruit quality were obtained by two foliar applications (10 day intervals) of potassium sulfate solution with $\mathrm{K}$ concentration of $2.5 \mathrm{~g} / 1$ during flowering stage. Beneficial effects of foliar application of $\mathrm{K}$ during vegetative and fruiting stages of several vegetable crops were also reported by Gupta and Sengar [37], Harneet-Kaur, et al. [38], and Kotepong et al. [39].

These beneficial effects were attributed to increased root growth leading to enhanced uptake of water and mineral nutrients $[2,16,40]$, optimal water adjustment in cell wall, and efficient translocation of sugars from source to sink $[41,42]$. Furthermore, $\mathrm{K}$ is required for activity of some enzymes [41,43].

\subsubsection{Photosynthetic Pigments}

Chlorophyll_a, and total phenols in the leaves were increased in the plants which received KMP foliar spray as compared to those without KMP application (Table 5). El-Tohamy et al. [35] reported that foliar $\mathrm{K}$ fertilization reduced electrolyte leakage, thus increased total chlorophyll content as compared to that of the plants without foliar fertilization. Shafeek et al. [40] demonstrated greater concentration of leaf pigments in pea plants with foliar application of $\mathrm{P}$ and $\mathrm{K}$ as compared to those in the plants without foliar fertilization. Our results also agree with the findings of Vigay et al. [44].

\subsubsection{Total Phenols}

Total phenols concentration significantly increased in the leaves of the plants that received foliar application of 100 ppm KMP as compared to that of the plants which received no KMP (Table 5). However, further increase in KMP concentration to $200 \mathrm{ppm}$ failed to show significant increase in leaf phenol content. These results agree with the conclusion of Li et al. [45] on maize and Nguyen et al. [46] on basil.

\subsection{Salinity $X$ Potassium Fertilizer}

\subsubsection{Growth}

Foliar spray of 200 ppm KMP improved all growth parameters across each irrigation water salinity (Table 6). The differences were significant only on fruit length, diameter, and weight. Hussein, et al. [21] demonstrated that the positive effects of foliar application of $\mathrm{P}$ and $\mathrm{K}$ was marked under different salt levels. Kaya, et al. [47] concluded that foliar application of $5 \mathrm{mM} \mathrm{KH}_{2} \mathrm{PO}_{4}$ solution maintained membrane permeability by decreasing electrolyte leakage from leaves of plants grown in high salinity conditions. This beneficial response appears to be due to the effects of salts on the osmotic pressure of soil solution and the toxicity of salts on the root and shoot tissues $([48,49])$.

Adequate $\mathrm{K}$ nutrition is important for osmo-regulation, maintenance of electrochemical equilibria in cells and its compartments, and regulation of enzyme activities [50]. Potassium has a crucial role in the energy status of the plant (Imas and Bansal, 1999) ${ }^{1}$, translocation and storage of assimilates, and maintenance of tissue water relations [51]. K plays a key role for enhancing crop quality. It improves fruit size and stimulates root growth. It is necessary for the translocation of sugars and formation of carbohydrates. $\mathrm{K}$ also provides resistance against pest and diseases, drought, and frost stresses [52]. Phosphorus is an essential nutrient and is a major building block of DNA molecules, thus, encouraging plant growth [53]. Adequate $\mathrm{P}$ availability is important for maintaining vigorous plant growth [54]. Phosphorus is important for nucleic acid synthesis, energy transfer processes, and carbohydrate metabolism. Phosphorus deficiency leads to decreased photosynthetic carbon fixation [55].

The interaction between salinity and KMP levels was significant. Plant biomass decreased with increasing salinity of the irrigation water. Increasing salinity levels resulted in smaller fruit size, higher soluble solid content (SSC) and decreased the $\mathrm{pH}$ of the fruit juice. Water use

${ }^{1}$ Imas, P. and Bansal, S.K. (1999) Potassium and integrated nutrient management in potato. Presented at the global conference on potato, December 6-11, New Delhi, India. 
Table 5. Photosynthetic pigments and total phenols in leaves of pepper plants as affected by foliar application of potassium mono phosphate (KMP).

\begin{tabular}{ccccccc}
\hline $\begin{array}{c}\text { KMP } \\
(\mathrm{ppm})\end{array}$ & $\begin{array}{c}\text { Chl_a } \\
(\mathrm{ppm})\end{array}$ & $\begin{array}{c}\text { Chl_b } \\
(\mathrm{ppm})\end{array}$ & $\begin{array}{c}\text { Carotenoids } \\
(\mathrm{ppm})\end{array}$ & $\begin{array}{c}\text { (Chl_a: Chl_b) } \\
\text { Ratio }\end{array}$ & $\begin{array}{c}\text { (Chl_a }+ \text { Chl_b): } \\
\text { Carotenoids Ratio }\end{array}$ & $\begin{array}{c}\text { Total phenols } \\
(\mathrm{mg} / 100 \mathrm{~g} \text { dry weight })\end{array}$ \\
\hline $0^{(1)}$ & 4.157 & 3.022 & 2.080 & 1.370 & 3.451 & 304 \\
100 & 5.907 & 2.975 & 2.437 & 1.921 & 3.592 & 495 \\
200 & 5.930 & 3.001 & 2.201 & 2.003 & 4.058 & 555 \\
LSD $(\mathrm{P} \leq 0.05)$ & 0.403 & NS & NS & NA & NA & 88 \\
\hline
\end{tabular}

${ }^{(1)}$ Distilled Water; NS = Non Significant; LSD = Least Significant Difference; NA = Not Applicable.

Table 6. Growth response of pepper plants to foliar application of different concentrations of potassium mono phosphate (KMP) across three different salinity levels in irrigation water.

\begin{tabular}{|c|c|c|c|c|c|c|c|c|c|c|c|c|}
\hline \multirow{2}{*}{$\begin{array}{l}\text { Salinity } \\
(\mathrm{dS} / \mathrm{m})\end{array}$} & \multirow{2}{*}{$\begin{array}{c}\text { KMP } \\
(\mathrm{ppm})\end{array}$} & \multirow{2}{*}{$\begin{array}{c}\text { Plant } \\
\text { Height }(\mathrm{cm})\end{array}$} & \multirow{2}{*}{$\begin{array}{l}\text { No. of } \\
\text { Leaves }\end{array}$} & \multirow{2}{*}{$\begin{array}{c}\text { Area of } \\
\text { leaves }\left(\mathrm{cm}^{2}\right)\end{array}$} & \multicolumn{2}{|c|}{ Fruit } & \multicolumn{3}{|c|}{ Fresh weight (g) } & \multicolumn{3}{|c|}{ Dry weight (g) } \\
\hline & & & & & Length $(\mathrm{cm})$ & Diameter $(\mathrm{cm})$ & Stem & Leaves & Fruits & Stem & Leaves & Fruits \\
\hline \multirow{3}{*}{0.47} & $0^{(1)}$ & 46.3 & 44.7 & 1082 & 3.9 & 4.5 & 26.5 & 27.7 & 17.5 & 3.5 & 4.4 & 3.7 \\
\hline & 100 & 46.7 & 51.3 & 1923 & 4.7 & 4.3 & 35.2 & 29.1 & 25.5 & 4.4 & 5.3 & 5.6 \\
\hline & 200 & 59.0 & 47.7 & 2158 & 5.8 & 5.1 & 28.6 & 26.2 & 29.05 & 5.5 & 6.0 & 8.4 \\
\hline \multirow{3}{*}{4.69} & $0^{(1)}$ & 31.3 & 31.7 & 957 & 3.7 & 3.2 & 12.0 & 18.5 & 18.38 & 4.2 & 3.3 & 3.6 \\
\hline & 100 & 39.3 & 33.7 & 824 & 3.5 & 3.0 & 24.0 & 20.0 & 17.13 & 3.4 & 4.8 & 3.4 \\
\hline & 200 & 39.0 & 31.0 & 1700 & 4.0 & 4.2 & 22.8 & 20.1 & 26.47 & 5.2 & 5.3 & 7.0 \\
\hline \multirow{3}{*}{9.38} & $0^{(1)}$ & 30.3 & 21.7 & 600 & 3.1 & 2.4 & 7.7 & 9.6 & 7.87 & 2.1 & 2.2 & 2.5 \\
\hline & 100 & 34.0 & 26.7 & 782 & 3.9 & 3.4 & 16.1 & 15.7 & 17.86 & 2.6 & 2.0 & 4.0 \\
\hline & 200 & 41.3 & 37.0 & 1253 & 4.3 & 3.3 & 19.7 & 17.1 & 15.31 & 3.3 & 3.7 & 3.2 \\
\hline \multicolumn{2}{|c|}{$\operatorname{LSD}(\mathrm{P} \leq 0.05)$} & NS & NS & NS & 0.9 & 0.8 & NS & NS & 3.68 & NS & NS & 3.7 \\
\hline
\end{tabular}

${ }^{(1)}$ Distilled water; NS = Non Significant; LSD = Least Significant Difference.

by the plants decreased with increasing salinity [12]. Kaya, et al. [47] concluded that foliar application of $5 \mathrm{mM}$ $\mathrm{KH}_{2} \mathrm{PO}_{4}$ solution maintained membrane permeability by decreasing electrolyte leakage from leaves of the plants grown in high salinity conditions.

\subsubsection{Photosynthetic Pigments}

Increased concentration of KMP in the foliar spray increased chl_a, chl_a + chl_b, and chl_a: chl_b ratio in plants irrigated with tap water or increased salinity irrigation water (Table 7). The interactions between salinity of irrigation water and KMP levels in foliar spray were not significant on the concentrations of chl_b and total carotenoids. Kaya, et al. [56] reported increased salinity decreased chl_a, and chl_b contents and application of $\mathrm{KNO}_{3}$ ameliorated the adverse effects of salt stress.

\subsubsection{Total Phenols}

Pepper plants without the salt stress and received KMP
(100 or $200 \mathrm{ppm}$ ) foliar application increased total phenols concentration in the leaves by 2.1 to 2.6 -fold as compared to that of the plants that received no foliar application of KMP (Table 7). The corresponding increase for the plants irrigated with low and high saline water were 1.6 to 1.8 -fold and 1.2 to 1.9 -fold, respectively.

\section{CONCLUSION}

Saline irrigation water, even at $4.69 \mathrm{dS} / \mathrm{m}$ significantly decreased growth and biomass production of pepper plants. The photosynthetic pigments and carotenoids content increased in plants irrigated with high salinity water. Two foliar applications of potassium mono phosphate (KMP), 21 and 35 days after planting, increased plant growth and fruit yield, particularly at the intermediate irrigation water salinity. Therefore, this study demonstrates the beneficial effects of foliar application of KMP to pepper plants by mitigating the negative effects 
Table 7. Effect foliar application of potassium mono phosphate (KMP) across three different salinity in irrigation water on photosynthetic pigments and total phenols in leaves of pepper plants.

\begin{tabular}{|c|c|c|c|c|c|c|c|c|}
\hline $\begin{array}{l}\text { Salinity } \\
(\mathrm{dS} / \mathrm{m})\end{array}$ & $\begin{array}{l}\mathrm{KMP} \\
(\mathrm{ppm})\end{array}$ & $\begin{array}{l}\text { Chl_a } \\
(\mathrm{ppm})\end{array}$ & $\begin{array}{l}\text { Chl_b } \\
(\mathrm{ppm})\end{array}$ & $\begin{array}{l}\text { Carotenoids } \\
(\mathrm{ppm})\end{array}$ & Chl_a + Chl_b & Chl_a:Chl_b & $\begin{array}{c}(\mathrm{Chl} \mathrm{a}+\mathrm{Chl} \text { Ch): } \\
\text { Carotenoids }\end{array}$ & $\begin{array}{c}\text { Total phenols } \\
\text { (mg/100g dry Weight) }\end{array}$ \\
\hline \multirow{3}{*}{$\begin{array}{c}0.47 \\
\text { (tap water) }\end{array}$} & DW & 2.08 & 2.9 & 1.84 & 4.98 & 0.73 & 2.69 & 171 \\
\hline & 100 & 4.44 & 2.4 & 2.11 & 6.84 & 1.68 & 3.22 & 441 \\
\hline & 200 & 4.63 & 2.61 & 1.92 & 7.24 & 1.78 & 3.77 & 365 \\
\hline \multirow{3}{*}{4.69} & DW & 4.79 & 2.64 & 1.97 & 7.43 & 1.82 & 3.77 & 275 \\
\hline & 100 & 5.45 & 2.57 & 2.17 & 8.02 & 2.12 & 3.69 & 507 \\
\hline & 200 & 5.73 & 2.42 & 2.16 & 8.15 & 2.36 & 3.77 & 433 \\
\hline \multirow{3}{*}{9.39} & DW & 5.60 & 3.58 & 2.43 & 9.18 & 1.56 & 3.77 & 466 \\
\hline & 100 & 7.83 & 3.99 & 3.13 & 11.82 & 1.96 & 3.77 & 536 \\
\hline & 200 & 7.43 & 3.98 & 2.53 & 11.41 & 1.87 & 4.51 & 868 \\
\hline \multicolumn{2}{|c|}{$\operatorname{LSD}(\mathrm{P} \leq 0.05)$} & 0.697 & NS & NS & 1.403 & NA & NA & 151.6 \\
\hline
\end{tabular}

DW = Distilled Water; NS = Non Significant NA = Not Applicable; LSD = Least Significant Difference; Chl = Chlorophyll.

of saline irrigation water. We highly recommend evaluation of these effects in field conditions across different soil types.

\section{REFERENCES}

[1] Rhoades, J.D., Kandiah, A. and Mashali, A.M. (1992) The use of saline waters for crop production. FAO Irrigation and Drainage, FAO, Rome, 48.

[2] Lee, S.K.D. (2006) Hot pepper response to interactive effects of salinity and boron. Plant Soil Environment, 52, 227-233.

[3] Gunes, A., Inal, A. and Alpaslan, M. (1996) Effect of salinity on stomatal resistance, proline and mineral composition of pepper. Journal of Plant Nutrition, 19, 389-396. doi:10.1080/01904169609365129

[4] Munns, R. and Termaat, A. (1986) Whole-plant response to salinity. Austrian Journal of Plant Physiology, 13, 143160. doi:10.1071/PP9860143

[5] Padem, H., Ocal, A. and Alan, R. (1999) Effect of humic foliar fertilizer on quality and nutrient content of eggplant and pepper seedlings. Acta Horticulturae, 491, 241-246.

[6] Lin, B., et al., (2000) Influence of calcium and nitrate on yield and quality of vegetables. Soils and Fertilizers, 2, 20-26.

[7] Fawzy, Z.F., Behairy, A.G. and Shehata, S.A. (2005) Effect of potassium fertilizer on growth and yield of sweet pepper plants (Capsicum annuum, L.). Egyptian Journal of Agriculture Research, 2, 599-610.

[8] Zhang, Y., Gu, W.L., Dai, J.Y. and Su, Z.X. (1991) Effects of chemicals on superoxide. Plant Physiology Communications, 2, 105-107.

[9] Grattan S.R. and Grieve, C.M. (1998) Salinity-mineral nutrient relations in horticultural crops. Scientia Horticulturae, 78, 127-157.

\section{doi:10.1016/S0304-4238(98)00192-7}

[10] Lopez, M.V. and Satti, S.M. (1996) Calcium and potassium-enhanced growth and. Plant Science, 114, 19-27. doi:10.1016/0168-9452(95)04300-4

[11] Caines, A.M. and Shennan, C. (1999) Interactive effects of $\mathrm{Ca}^{2+}$ and $\mathrm{NaCl}$ salinity onthe growth of two tomato genotypes differing in $\mathrm{Ca}^{2+}$ use efficiency. Plant Physiology and Biochemistry, 37, 569-576.

[12] Yurtseven, E., Kesmez, G.D. and Ünlükara, A. (2005) The effects of water salinity and potassium levels on yield, fruit quality and water consumption of a native central anatolian tomato species (Lycopersicon esculantum). Agricultural Water Management, 78, 128-135. doi:10.1016/j.agwat.2005.04.018

[13] Von Wettstein, D. (1957) Chlorophyll letale and der submikroskopishe formweschselder plastiden. Experimental cell Research, 12, 427. doi:10.1016/0014-4827(57)90165-9

[14] Titto, R.S. (1985) Phenolic constituents in the leaves of northern willows: Methods for analysis of certain phenolics. Journal of Agricultural Food Chemistry, 33, 212217.

[15] Snedecor, G.W. and Cochran, W.G. (1980) Statistical methods. 8th Edition, Iowa State University Press, Ames.

[16] Chartzoulakis, K.S. and Klapaki, G. (2000) Response of two greenhouse pepper hybrids to $\mathrm{NaCl}$ salinity during different growth stages. Scientia Horticulturae, 86, 247260. doi:10.1016/S0304-4238(00)00151-5

[17] Steduto, P., Albrizio, R., Giorio, P. and Sorrentino, G. (2000) Gas-exchange response and stomatal and nonstomatal limitations to carbon assimilation of sunflower under salinity. Environmental and Experimental Botany, 44, 243-255. doi:10.1016/S0098-8472(00)00071-X

[18] Morales-Garcia, Stewart, K.A. and Seguin, P. (2008) Effects of saline water on growth and physiology of bell pepper seedlings. International Journal of Vegetable Sci- 
ence, 14, 121-138. doi:10.1080/19315260801934431

[19] Hussein, M.M., Gaballah, M.S. and El-Faham, S.Y. (2004) Amino acids in grains of barley as affected by benzyl adenine and salinity from diluted seawater. Journal of Applied Science, 5, 655-658.

[20] Zafar, S., Ashraf, M.Y. and Ashraf, M. (2005) Protease activity and associated changes during germination and early seedling stages of cotton grown under saline conditions. International Journal of Biology, 1, 103-107. doi:10.3923/ijb.2005.103.107

[21] Hussein, M.M., Shaaban, M.M. and El-Saady, A.M. (2008) Response of cowpea plants grown under salinity stress to PK-foliar application. American Journal of Plant Physiology, 3, 81-88. doi:10.3923/ajpp.2008.81.88

[22] Hare, P.D., Cress, W.A. and Van Staden, J. (1997) Cytokinins and water stress: The involvement of cytokinins in plant responses to environmental stress. Plant Growth Regulation, 23, 79-103. doi:10.1023/A:1005954525087

[23] Hussein, M.M. and El-Greatly, N.H. (2007) Influences of Alph-tochopherol and potassium dihydrogen phosphate on growth and endogenous phytohormones of onion plants grown under salinity stress. Journal of Agricultural Science, 32, 9141-9151.

[24] Kaya, C., Tuna, A.L. and Yokaş, I. (2009) The role of plant hormones in plants under salinity stress tasks for vegetation science. Salinity and Water Stress, 44, 45-50. doi:10.1007/978-1-4020-9065-3_5

[25] Demural, M.A., Aydin, M. and Youlmaz, A. (2005) Effect of salinity on growth, chemical composition and antioxidative enzyme activity of two malting barley (Hordeum vulgare L.) cultivars. Turkish Journal of Biology, 2, 8-12.

[26] Hussein, M.M. and Oraby, S.H. (2008) Growth and antioxidant enzymes activity in onion plants as affected by thiamine and salinity. Plant Nutrition Management under Water Stress Conditions. 17th International Symposium of CIEC, Cairo, 260-278.

[27] Abd El-Baky, H.H., Hussein, M.M. and Baroty, G.S. (2008) Algal extraction improve antioxidants defense abilities and salt tolerance of wheat plant irrigated with sea water. Electronic Journal of Environmental Agiculture and Food Chemistry, 7, 281-283.

[28] Mousavi, A., Lessani, H., Babalar, M., Talaei, A.R. and Fallahi, E. (2008) Influence of salinity on chlorophyll, leaf water potential, total soluble sugars, and mineral nutrients in two young olive cultivars. Journal of Plant Nutrition, 31, 1906-1916. doi:10.1080/01904160802402807

[29] Azooz, M.M., Shadded, M.A. and Abdel-latef, A.A. (2004) The accumulation and compartmentation of proline in relation to salt tolerance of three sorghum cultivars. Indian Journal of Plant Physiology, 9, 1-8.

[30] Dagar, J.C., Bhagwan, H. and Kumar, Y. (2004) Effect on growth performance and biochemical contents of Salvadora persica when irrigated with water of different salinity. Indian Journal of Plant Physiology, 9, 234-238,

[31] Levitt, J. (1980) Responses of plants to environmental stresses. Academic Press, New York.

[32] Jaleel, A., Sankar, B., Sridharan, R. and Panneersel, R. (2008) Soil salinity alters - Growth, chlorophyll content, and secondary metabolite accumulation in Catharanthus roseus. Turkish Journal of Biology, 32, 79-83.

[33] Chartzoulakis, K.S. (2005) Salinity and olive: Growth, salt tolerance, photosynthesis and yield. Agricultural Water Management, 78, 108-121. doi:10.1016/j.agwat.2005.04.025

[34] Ben Dkhil, B. and Denden, M. (2010) Salt stress induced changes in germination, sugars, starch and enzyme of carbohydrate metabolism in Abelmoschus esculentus L. (Moench.) seeds. African Journal of Agricultural Research, 5, 1412-1418.

[35] El-Tohamy, W.A., Ghoname, A.A. and Abou-Hussein, S.D. (2006) Improvement of pepper growth and productivity in sandy soil by different fertilization treatments under protected cultivation. Journal of Applied Sciences Research, 2, 8-12.

[36] Fawzy, Z.F., El-Nemr, M.A. and Saleh, S.A. (2007) Influence of levels and methods of potassium fertilizer application on growth and yield of eggplant. Journal of Applied Sciences Research, 3, 42-49.

[37] Gupta, C.R. and Sengar, S.S. (2000) Response of tomato (Lycopersicon esculentum Mill.) to nitrogen and potassium fertilization in acidic soil of Bastar. Vegetable Science, 27, 94-95.

[38] Harneet-Kaur, Thakur, J.C. and Neena-Chawla, (2003) Effect of nitrogen and potassium on growth, yield and quality of tomato (Lycopersicon esculentum Mill.) cv. Punjab Upma. Haryana Journal of Horticultural Sciences, 32, 286-288.

[39] Kotepong, P., Thongket, T., Kamlung, A. and Verasan, J. (2003) Effect of nitrogen and potassium on growth and yield of cherry tomato cv. CH154 in hydroponics. Proceedings of 41st Kasetsart University Annual Conference on Agricultural Extension and Communication, Bangkok, 3-7 February 2003, 97-203.

[40] Shafeek, M.R., El-Zeiny, A.H. and Ahmed, M.E. (2005) Effect of phosphate and potassium fertilizer on growth, yield and seed composition of pea plants in new reclaimed soils. Asian Journal of Plant Science, 4, 608-612. doi:10.3923/ajps.2005.608.612

[41] Abdel-Wahab, A.M. and Abd-Allaa, M.H. (1995) The role of potassium fertilizer in nodulation and nitrogen fixation of faba bean (Vicia faba L.) plants under drought stress. Biology and Fertility of Soils, 20, 147-150. doi:10.1007/BF00336594

[42] Kato, T., Taniguchi, A., Shinmura, D. and Horibata, A. (2004) Sucrose-metabolism enzymes in developing rice endosperm: Their relations to grain filling of rice cultivars with extra-heavy panicles. Proceedings of the 4th International Crop Science Congress, Brisbane, 26 September-1 October 2004.

[43] Paul, R.H. (1990) The role of potassium. The Agronomy Guide, Aqua Botanic, Keizer.

[44] Vigay, N., Kumar, A. and Bhoite, A. (2009) Influence of nitrogen, phosphorus and potassium fertilizer on biochemical contents of Asparagus racemonus. Research Journal of Environmental Science, 3, 285-291. doi:10.3923/rjes.2009.285.291 
[45] Li, W., Ping, H. and Jiyun, J. (2009) Potassium influenced phenylalanine ammonia-lyase, peroxidases and polyphenol oxidases in Fusarium graminearum infected maize (Zea mays L.). Proceedings of the International Plant Nutrition Colloquium XVI, UC Davis, 19 August 2009.

[46] Nguyen, P.M., Kwee, E.M. and Niemeyer, E.D. (2010) Potassium rate alters the antioxidant capacity and phenolic concentration of basil (Ocimum basilicum L.) leaves. Food Chemistry, 123, 1235-1241. doi:10.1016/j.foodchem.2010.05.092

[47] Kaya, C., Higgs, D. and Kimak, H. (2001) The effect of high salinity $(\mathrm{NaCL})$ and supplementary phosphorus and potassium on physiology and nutrient development of spinach. Bulgarian Journal of Plant Physiology, 27, 4759.

[48] Wimmer, M.A., Muehling, K.H., Lauchli, A., Brown, P.H. and Goldbach, H.E. (2001) Interaction of salinity and boron toxicity in wheat (Triticum aestivum L.). Developments in Plant and Soil Sciences, 2001, 46-247.

[49] Matichenkov, V.V. and Kosobrukhov, A.A. (2004) SI effect on the plant resistance to salt toxicity. 13th International Soil Conservation Organisation Conference, Brisbane, 4-8 July 2004.

[50] Hsiao, C. and Läuchli, A. (1986) Role of potassium in plant-water relation. In: Tinker and Läuchli, A., Eds., Advances in Plant Nutrition 2, Praeger, New York.
[51] Geissler, N. Hussin S. and Koyro, H.W. (2009) Interactive effects of $\mathrm{NaCl}$ salinity and elevated atmospheric $\mathrm{CO}_{2}$ concentration on growth, photosynthesis, water relations and chemical composition of the potential cash crop halophyte Aster tripolim L.. Environmental and Experimental Botany, 65, 220-231. doi:10.1016/j.envexpbot.2008.11.001

[52] Marschner, H. (1995) Mineral nutrition of higher plants. 4th Edition, Academic Press, London.

[53] Pant, H.K.and Reddy, K.R. (2003) Potential internal loading of phosphorus. Aricultural Land Water Research, 37, 965-972.

[54] Shaheen, A.M., Abdel-Mouty, M.M., Ali, A.H. and Rizk, F.A. (2007) Natural and chemical phosphorus fertilizers affect onion plant growth, bulbs yield and some physical and chemical properties. Australian Journal of Basic and Applied Sciences, 1, 519-524.

[55] Sivak, M.N. and Walker, D.A. (1986) Photosynthesis in vivo can be limited by phosphate supply. New Phyto, 102, 499-512. doi:10.1111/j.1469-8137.1986.tb00826.x

[56] Kaya, C., Tuna, A.L., Ashraf, M. and Altunlu, H. (2007) Improved salt tolerance of melon (Cucumis melo L.) by the addition of proline and potassium nitrate. Environmental and Experimental Botany, 60, 397-403. doi:10.1016/j.envexpbot.2006.12.008 